\title{
Methylation of SOCS3 in Myeloproliferative Neoplasms and Secondary Erythrocytosis/Thrombocythemia
}

\author{
Miyeloproliferatif Neoplazmlar ve Sekonder \\ Eritrositoz/Trombositemide SOCS3 Metilasyonu
}

\author{
Deniz Torun'1, Oral Nevruz², Mesut Akyol ${ }^{3}$, Salih Kozan¹, Muhterem Bahçe1, Şefik Güran ${ }^{4}$, Cengiz Beyan² \\ ${ }^{1}$ Gülhane Military Medical Faculty, Department of Medical Genetics, Ankara, Turkey \\ ${ }^{2}$ Gülhane Military Medical Faculty, Department of Hematology, Ankara, Turkey \\ ${ }^{3}$ Gülhane Military Medical Faculty, Department of Biostatistics, Ankara, Turkey \\ ${ }^{4}$ Gülhane Military Medical Faculty, Department of Medical Biology, Ankara, Turkey
}

\begin{abstract}
:
Objective: Myeloproliferative neoplasms (MPNs) like essential thrombocythemia (ET), polycythemia vera (PV), and primary myelofibrosis (PMF) are acquired clonal hematopoietic stem cell disorders and originate from a multipotent hematopoietic stem cell. The SOCS1 and SOCS3 genes are negative regulators of the JAK/STAT signal pathway. In this study we investigate the promoter methylation of these genes in the pathogenesis of MPNs and secondary erythrocytosis/thrombocythemia.

Materials and Methods: Promoter methylation of SOCS1 and SOCS3 genes was analyzed with methylation-specific PCR. PCR products were analyzed by agarose gel electrophoresis.

Results: No disease-specific CPG island methylation of SOCS1 was observed. Hypermethylation of the SOCS3 promoter was identified in 5 out of 19 (26.3\%) PV cases, 2 out of 21 (9.5\%) ET cases, 1 out of 5 (20\%) PMF cases, and 9 out of 42 (21.4\%) cases of secondary erythrocytosis/thrombocythemia.

Conclusion: The results revealed that promoter methylation of the SOCS3 gene suggests a possible role for SOCS3 methylation in the pathogenesis of MPNs and secondary erythrocytosis/thrombocythemia.
\end{abstract}

Key words: Myeloproliferative neoplasm, SOCS1, SOCS3, Secondary erythrocytosis/thrombocythemia

Özet:

Amaç: Esansiyel trombositemi (ET), polisitemia vera (PV), primer miyelofibrozis (PMF) gibi miyeloproliferatif neoplazmlar (MPN) kazanılmış klonal hematopoetik kök hüicre hastalığı olup multipotent hematopoietik kök hüicreden köken alırlar. SOCS1 ve SOCS3 genleri JAK/STAT sinyal yolağının negatif düzenleyicileridir. Bu çalışmada MPN ve sekonder eritrositoz/trombositemi patogenezinde bu genlerin promotor metilasyonunu incelemeyi amaçladık.

Address for Correspondence: Deniz TORUN, M.D.,

Gülhane Military Medical Faculty, Department of Medical Genetics, Ankara, Turkey

Phone: +90 3123043585 E-mail: dtorun@gata.edu.tr

Received/Geliş tarihi : August 08, 2011

Accepted/Kabul tarihi : September 27, 2012 
Gereç ve Yöntemler: SOCS1, SOCS3 genlerinin promotor metilasyonu, metilasyon spesififk PCR ile incelendi. PCR ürünleri agaroz jel elektroforezinde analiz edildi.

Bulgular: SOCS1 geninde CPG adacıklarında hastalıkla ilişkili metilasyon bulunamadı. 19 PV olgusunun 5'inde (\%26,3), 21 ET olgusunun 2'sinde (\%9,5), 5 PMF olgusunun 1'inde (\%20), 42 sekonder eritrositoz/trombositemi olgusunun 9'unda $(\% 21,4)$ SOCS3 promotor metilasyonu saptand.

Sonuç: SOCS3 geni promotor metilasyonu MPN ve sekonder eritrositoz/trombositemi patogenezinde etkili olarak görïnmektedir.

Anahtar Sözcükler: Miyeloproliferatif Neoplazi, SOCS1; SOCS3; Sekonder eritrositoz/trombositemi

\section{Introduction}

Myeloproliferative neoplasms (MPNs) are a group of diseases of the bone marrow in which excess cells are produced. They are related to, and may evolve into, myelodysplastic syndrome (MDS) and acute myeloid leukemia (AML), although the MPNs on the whole have a much better prognosis than these conditions. The classic MPNs are polycythemia vera (PV), essential thrombocythemia (ET), primary myelofibrosis (PMF), and chronic myelogenous leukemia (CML). They were originally grouped together based on their shared phenotype of myeloproliferation [1]. All of these neoplasms are acquired clonal hematopoietic stem cell disorders, originating from a multipotent hematopoietic stem cell. Cytogenetic and/or molecular genetic analyses are mandatory for differential diagnosis. Apart from the BCR/ABL rearrangement in CML, the JAK2 and MPL mutations play a crucial role in the pathogenesis of PV, ET, and PMF [2,3].

The JAK-STAT signaling pathway transmits information from chemical signals outside the cell, through the cell membrane, and into gene promoters on the DNA in the cell nucleus, which causes DNA transcription and activity in the cell [4]. The suppressor of cytokine signaling (SOCS) proteins inhibit the cytokine signaling cascade by using the JAK/STAT pathway in a cell [5]. Expression of SOCS1 and SOCS3 genes leads to reduced JAK and STAT phosphorylation via binding of the JHl domain and cytokine receptor of JAK, respectively $[6,7,8]$. Epigenetic mechanisms such as DNA methylation regulate DNA structure and gene expression in a cell. Abnormal epigenetic mechanisms take place in the development of many diseases, including cancer. Downregulation of a gene due to methylation has been demonstrated in various studies, including the SOCS1 and SOCS3 genes $[9,10,11]$.

In this study, the effects of aberrant methylation of $\mathrm{CpG}$ islands within the promoter region of SOCS1 and SOCS3 genes were demonstrated in the pathogenesis of PV, ET, PMF, and secondary erythrocytosis/thrombocythemia.

\section{Materials and Methods}

This study was approved by the appropriate local ethics committee. Participants were ascertained according to the 2008 World Health Organization (WHO) classification system [1]. Written informed consent was obtained from all participants. A cohort of 87 patients, which included 19 cases of PV, 21 cases of ET, 5 cases of PMF, and 42 cases of secondary erythrocytosis/thrombocythemia, was enrolled to investigate the role of SOCS1 and SOCS3 promoter methylation. The control group comprised 29 healthy individuals. JAK2 V617F mutation analysis was used in differential diagnosis of MPNs and secondary erythrocytosis/thrombocythemia.

Mutation Analysis of JAK2 V617F: DNAs were isolated from peripheral blood samples in each case by using the NucleoSpin Blood Kit (Macherey-Nagel, Germany). JAK2 V617F mutation was determined in RT-PCR analyses by using a kit (JAK2 Type 1 PCR System, Dr Zeydanl, Ankara, Turkey). The PCR conditions were $95^{\circ} \mathrm{C}$ for $10 \mathrm{~min}$, followed by 32 cycles of $95^{\circ} \mathrm{C}$ for $15 \mathrm{~s}$ and $60^{\circ} \mathrm{C}$ for $1 \mathrm{~min}$.

Methylation Analysis of SOCS1 and SOCS3 CpG Islands: Genomic DNA from patients and controls were modified with sodium bisulfite using the CpGenomeTM Fast DNA Modification Kit (Chemicon International, USA and Canada). The efficacy of bisulfite modification was assessed with methylated control samples (CpG WIZ® DAP-kinase Amplification Kit, Chemicon). Bisulfite-modified DNA samples were amplified by methylationspecific PCR by using methylation-specific primers and unmethylation-specific primers for the promoter region of SOCS1 and SOCS3 genes, as described by Liu et al. and Fourouclas et al., respectively $[10,11]$. The primer sequences and their locations relative to the transcription start sites were noted as follows:

SOCS1-MF 5'-TTGTTCGGAGGTCGGATTT-3' (nt -291 to 272); SOCS1-MR 5'-ACTAAAACGCTACGAAACCG-3' (nt -93 to 74); SOCS1-UF 5'-TTTTTTGGTGTTGTTTGGAGGTTGGATTTT-3' (nt -301 to -272); SOCS1-UR 5'-AAAACAAAACAATAAACTA AAACACTACAAAACCA-3' (nt -108 to -74); SOCS3-MF 5'GAGGGGTCGTTGTTAGGAAC-3' (nt -1265); SOCS3-MR 5'ACAAAAACCGAAAAAAACGC-3' (nt -1176); SOCS3-UNF 5'-GGAGGGGTTGTTGTTAGGAAT-3' (nt -1266); SOCS3-UNR 5'CAAAAACAAAAACCAAAAAAAACA-3' (nt -1175) $[10,11]$.

Bisulfite-modified DNA samples from patients and controls were amplified by PCR reaction in a total reaction volume of $25 \mu \mathrm{L}$ containing 1X PCR buffer (Bioron, Germany), $1.5 \mathrm{mM} \mathrm{MgCl}$, 0.2 mM dNTP, 0.4 pmol of each primer for SOCS1, and 1 pmol of each primer for SOCS3, using 1.5 U hot-start Taq polymerase (Bioron) on a thermal cycler (Bio-Rad, USA). The PCR conditions were 95 ${ }^{\circ} \mathrm{C}$ for $5 \mathrm{~min}$, followed by 40 cycles of $95^{\circ} \mathrm{C}$ for $30 \mathrm{~s}, 60^{\circ} \mathrm{C}$ for 40 $\mathrm{s}$, and $72{ }^{\circ} \mathrm{C}$ for $40 \mathrm{~s}$ with a final extension at $72{ }^{\circ} \mathrm{C}$ for $10 \mathrm{~min}$. PCR products were visualized using agarose gel electrophoresis.

Statistical Analysis: Statistical analysis was performed using SPSS 15.00 for Windows (SPSS Inc., Chicago, IL, USA) and Microsoft Excel 2003. The Shapiro-Wilks test was used to assess 
normal distribution. Descriptive data are expressed as mean \pm standard deviation. Skewed data are shown as median and interquartile range (IQR). Chi-square (chi-square, Fisher exact, or likelihood ratio) tests were used for comparisons of JAK2 and SOCS3 among sub-groups. Categorical data are shown as numbers and percentages. The level of significance was set at $\mathrm{p} \leq 0.05$.

\section{Results}

JAK2 V617F mutation and methylation analysis of SOCS1/SOCS3 CpG islands were performed in 45 cases of MPNs, 42 cases of secondary erythrocytosis/thrombocythemia, and for 29 control individuals. Age, sex, and blood count characteristics of all patients and controls are summarized in Table 1.

JAK2 V617F mutation as observed in our series is summarized in Table 2. Seventeen out of 19 PV patients (89.5\%), 11 out of 21 ET patients (52.4\%), and 2 out of 5 PMF patients (40.0\%) revealed
JAK2 V617F mutations. The JAK2 V617F mutation was not observed in secondary erythrocytosis/thrombocythemia patients or in the healthy control group (Table 2).

SOCS1 and SOCS3 CpG island methylation patterns of the study groups are presented in Table 2. The CpG islands analyzed in SOCS1 and SOCS3 genes were inside the promoter regions of these genes. MPN patients, secondary erythrocytosis/thrombocythemia patients, and the control group were negative for the methylation of the SOCS1 promoter region (Figure 1; Table 2). Five out of 19 PV patients, 2 out of 21 ET patients, 1 out of 5 ET patients, and 9 out of 42 secondary erythrocytosis/thrombocythemia patients revealed hypermethylation of the SOCS3 promoter region (Figure 2; Table 2). The control group was negative for the methylation of the SOCS3 promoter region. Four out of 5 PV patients and 2 out of 2 ET patients carrying methylation of the SOCS3 promoter region were concurrently positive for the JAK2 V617F mutation.

Table 1: Age, sex, and blood count characteristics of the patients and control subjects.

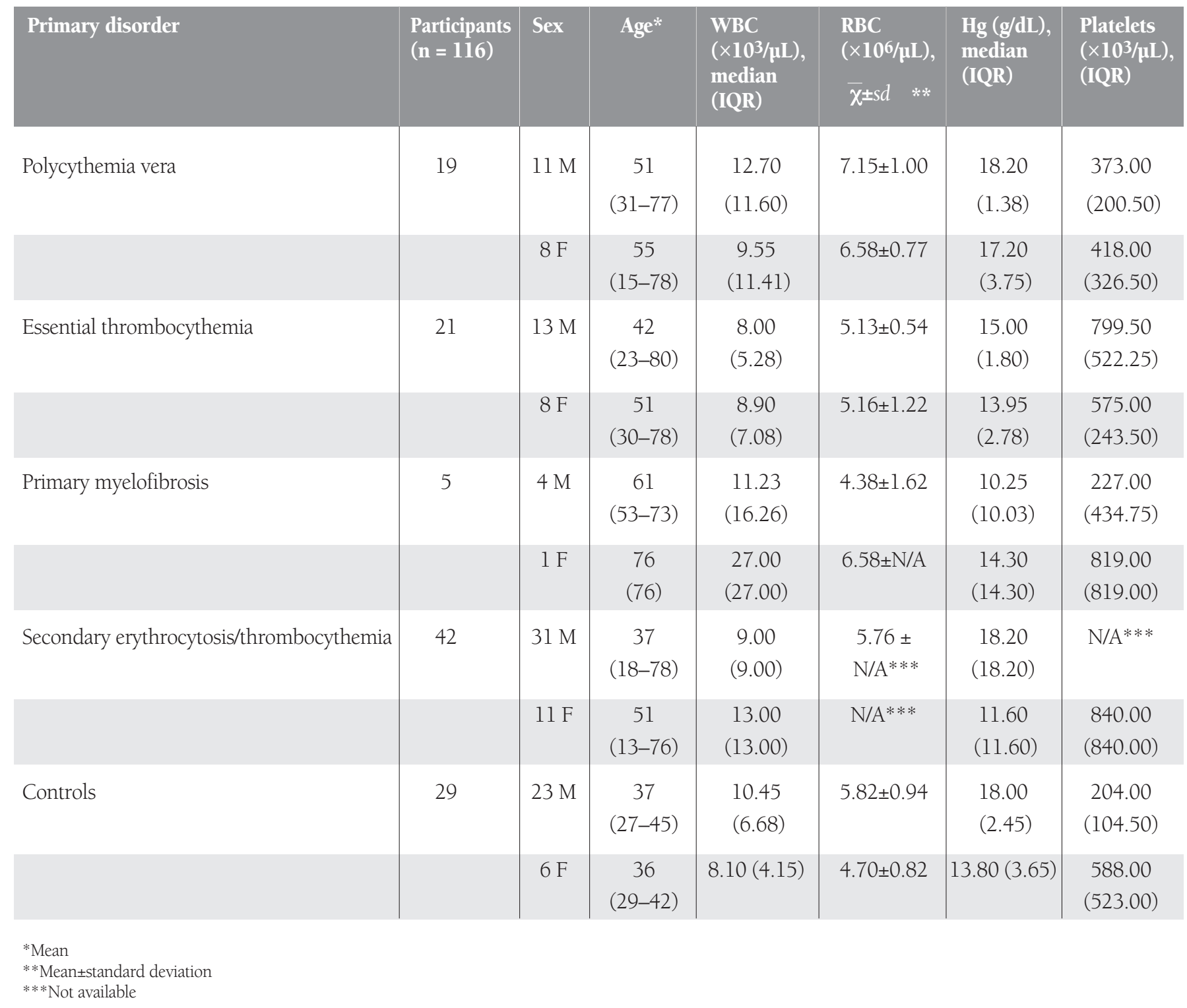




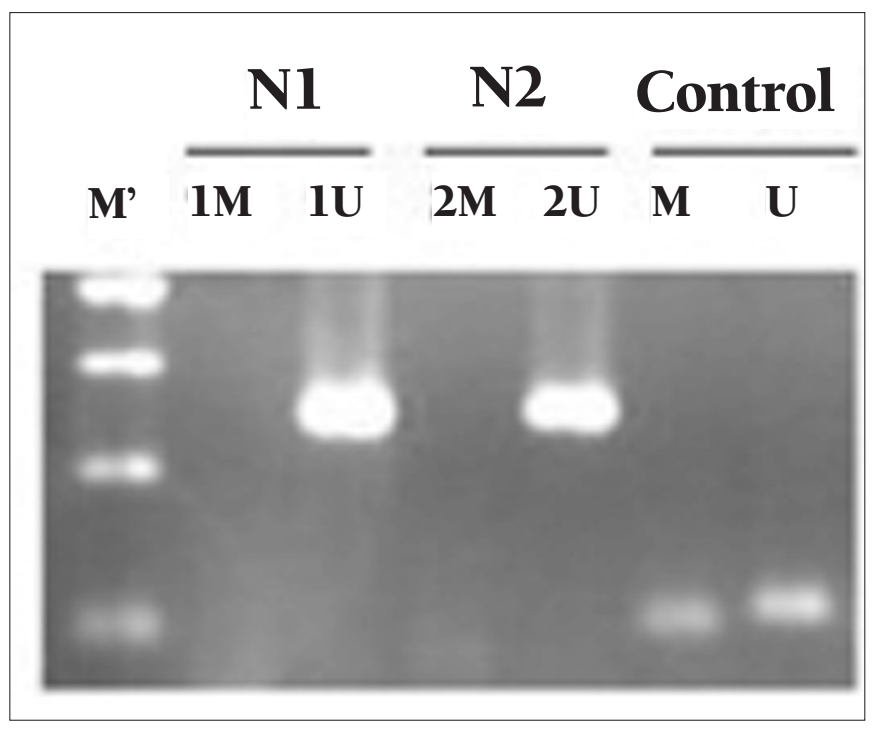

Figure 1: Methylation-specific PCR amplification of SOCS1 promoter region. U: unmethylated, M: methylated, M': molecular weight marker (100 bp). N1-N2: unmethylated. Presence of bands in control groups indicates the efficacy of bisulfite treatment.

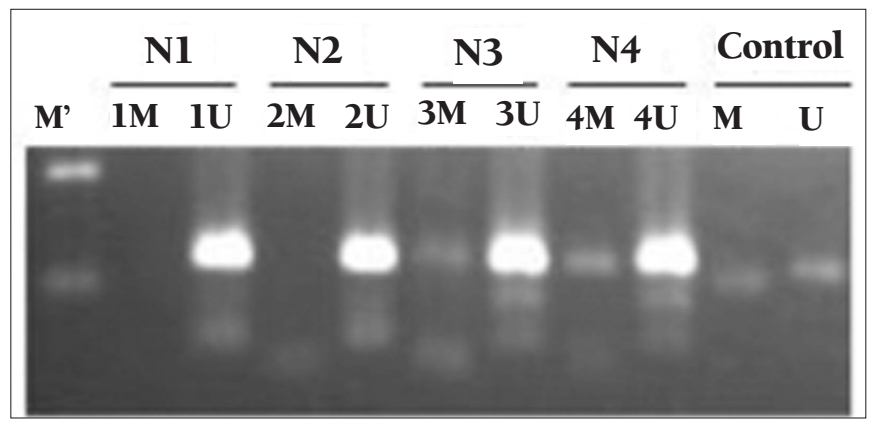

Figure 2: Methylation-specific PCR amplification of SOCS3 promoter region. U: unmethylated, M: methylated, M': molecular weight marker (100 bp). N1-N2: unmethylated, N3-N4: methylated. Presence of bands in control groups indicates the efficacy of bisulfite treatment.

\section{Discussion}

Classification of MPNs was based on the clinical phenotype of these disorders and histological patterns. In recent years, many advances have occurred in the understanding and management of MPNs. Updated WHO classification of MPNs was primarily based on the proliferation capacity of the cell lines and the amount of bone marrow fibrosis. These findings were combined with clinical, laboratory, and cytogenetic/molecular genetic features [1,12].

As an acquired mutation, JAK2 V617F plays a key role in the pathogenesis of MPNs $[2,13,14,15]$. The JAK2 protein is a cytoplasmic tyrosine kinase and takes part in signal transduction [16]. A single amino acid substitution (valine to phenylalanine) in the JAK2 tyrosine kinase encoding gene causes uncontrolled hematopoiesis. JAK2 V617F mutation was reported in 90\%-95\% of PV, $50 \%$ of PMF, and $40 \%-50 \%$ of ET patients in the literature $[17,18,19]$. In our study, $89.5 \%$ of PV, $52.4 \%$ of ET, and $40.0 \%$ of PMF patients revealed JAK2 V617F mutation. These results were in line with previous reports. Secondary erythrocytosis/ thrombocythemia patients and the control group were negative for the JAK2 V617F mutation, as expected.

Epigenetic changes, which are important for transcriptional control, may cause various diseases [20]. In our series, the SOCS1 promoter region did not reveal any methylation patterns in MPN patients, secondary erythrocytosis/thrombocythemia patients, or the control group. These findings suggest that methylation of the SOCS1 promoter region does not emerge as a molecular mechanism during the progression of MPNs and secondary erythrocytosis/thrombocythemia. These results are similar to those of a previously reported study in the literature [11].

SOCS3 promoter methylation represents an important mechanism in the pathogenesis of MPNs. Recently, Fourouclas et al. reported the methylation of SOCS3 in $32.0 \%$ of patients with PMF [11]. Our results show differences in some aspects. In our study, PV (26.3\%) and ET (9.5\%) patients also revealed SOCS3 promoter methylation, in addition to the PMF patients. This finding suggests that promoter methylation of the SOCS3 gene not only plays a role in the pathogenesis of PMF but also plays a key role in the pathogenesis of PV and ET.

Table 2: Frequency of JAK2 V617F and SOCS1/SOCS3 promoter methylation in the study groups.

\begin{tabular}{|c|c|c|c|c|c|}
\hline Primary disorder & $\begin{array}{l}\text { Participants } \\
(n=116)\end{array}$ & $\begin{array}{l}\text { JAK2 } \\
\text { V617F }\end{array}$ & SOCS1 & SOCS3 & $(*)$ \\
\hline Polycythemia vera & 19 & $17 / 19(89.5 \%)$ & $0 / 19(0.0 \%)$ & $5 / 19(26.3 \%)$ & $4 / 5$ \\
\hline Essential thrombocythemia & 21 & $11 / 21(52.4 \%)$ & $0 / 21(0.0 \%)$ & $2 / 21(9.5 \%)$ & $2 / 2$ \\
\hline Primary myelofibrosis & 5 & $2 / 5(40.0 \%)$ & $0 / 5(0.0 \%)$ & $1 / 5(20.0 \%)$ & \\
\hline Controls & 29 & $0 / 29(0.0 \%)$ & $0 / 29(0.0 \%)$ & $0 / 29(0.0 \%)$ & \\
\hline Total & 116 & 30 & 0 & 17 & \\
\hline
\end{tabular}

(*): JAK2 V617F and SOCS3 promoter methylation evident in the same patient. 
We next compared the MPNs among themselves for the frequency of SOCS3 promoter methylation. SOCS3 promoter hypermethylation did not exhibit any statistical difference among $\mathrm{PV}, \mathrm{ET}$, and PMF (p>0.05). This finding suggests that SOCS3 promoter hypermethylation may be a useful finding in the definition of MPNs but cannot be used as a tool of differential diagnosis.

In this study, secondary erythrocytosis/thrombocythemia patients were also analyzed for SOCS3 promoter methylation. In this group, 9 out of 42 (21.4\%) patients revealed aberrant SOCS3 promoter methylation. It seems that the agents that play a crucial role in the pathogenesis of secondary erythrocytosis/ thrombocythemia may show the effects through epigenetic changes. To our knowledge, the finding of SOCS3 promoter methylation in secondary erythrocytosis/ thrombocythemia has been revealed here for the first time in the literature, but longterm clinical and laboratory follow-up is needed to observe the effect of hypermethylation on the course of disease and whether or not the hypermethylation abates.

The coincidental association of SOCS3 promoter methylation and JAK2 V617F mutation is an important finding. Four out of 5 PV patients and 2 out of $2 \mathrm{ET}$ patients carrying methylation of the SOCS3 promoter region were concurrently positive for the JAK2 V617F mutation and statistical analysis revealed that the presence/absence of JAK2 V617F mutation had no effect on the existence of SOCS3 promoter methylation $(\mathrm{p}>0.05)$. These findings represent the fact that promoter methylation in the SOCS3 gene and the JAK2 V617F mutation might be independent. However, this finding should be supported with SOCS3 mRNA expression studies, and clinical outcomes of the patients must be compared to establish its importance in the pathogenesis and prognosis of MPN progression.

In conclusion, SOCS3 promoter hypermethylation represents a crucial epigenetic event in the pathogenesis of MPNs and secondary erythrocytosis/thrombocythemia. For long-term clinical affects, further studies are needed.

\section{Acknowledgment}

This study was supported by the Gülhane Military Medical Academy Research and Development Center, Ankara, Turkey.

\section{References}

1. Wadleigh M, Tefferi A. Classification and diagnosis of myeloproliferative neoplasms according to the 2008 World Health Organization criteria. Int J Hematol 2010;91:174-179.

2. Levine RL, Wadleigh M, Cools J, Ebert BL, Wernig G, Huntly BJ, Boggon TJ, Wlodarska I, Clark JJ, Moore S, Adelsperger J, Koo S, Lee JC, Gabriel S, Mercher T, D'Andrea A, Fröhling S, Döhner K, Marynen P, Vandenberghe P, Mesa RA, Tefferi A, Griffin JD, Eck MJ, Sellers WR, Meyerson M, Golub TR, Lee SJ, Gilliland DG. Activating mutation in the tyrosine kinase JAK2 in polycythemia vera, essential thrombocythemia, and myeloid metaplasia with myelofibrosis. Cancer Cell 2005;7:387-397.
3. Daly S, Conneally E, Langabeer SE. Identification of MPL W515L/K mutations in patients with primary myelofibrosis and essential thrombocythaemia by allele-specific polymerase chain reaction. Acta Haematol 2009;121:221-222.

4. Aaronson DS, Horvath CM. A road map for those who don't know JAK-STAT. Science 2002;296:1653-1655.

5. Greenhalgh CJ, Hilton DJ. Negative regulation of cytokine signaling. J Leukoc Biol 2001;70:348-356.

6. Starr R, Hilton DJ. Negative regulation of the JAK/STAT pathway. Bioessays 1999;21:47-52.

7. Sasaki A, Yasukawa H, Shouda T, Kitamura T, Dikic I, Yoshimura A. CIS3/SOCS-3 suppresses erythropoietin (EPO) signaling by binding the EPO receptor and JAK2. J Biol Chem 2000;275:29338-29347.

8. Yasukawa H, Misawa H, Sakamoto H, Masuhara M, Sasaki A, Wakioka T, Ohtsuka S, Imaizumi T, Matsuda T, Ihle JN, Yoshimura A. The JAK-binding protein JAB inhibits Janus tyrosine kinase activity through binding in the activation loop. EMBO J 1999;18:1309-1320.

9. Johan MF, Bowen DT, Frew ME, Goodeve AC, Reilly JT. Aberrant methylation of the negative regulators RASSFIA, SHP- 1 and SOCS-1 in myelodysplastic syndromes and acute myeloid leukaemia. Br J Haematol 2005;129:60-65.

10. Liu TC, Lin SF, Chang JG, Yang MY, Hung SY, Chang CS. Epigenetic alteration of the SOCS1 gene in chronic myeloid leukaemia. Br J Haematol 2003;123:654-661.

11. Fourouclas N, Li J, Gilby DC, Campbell PJ, Beer PA, Boyd EM, Goodeve AC, Bareford D, Harrison CN, Reilly JT, Green AR, Bench AJ. Methylation of the suppressor of cytokine signaling 3 gene (SOCS3) in myeloproliferative disorders. Haematologica 2008;93:1635-1644.

12. Vannucchi AM, Guglielmelli P, Tefferi A. Advances in understanding and management of myeloproliferative neoplasms. CA Cancer J Clin 2009;59:171-191.

13. James C, Ugo V, Le Couédic JP, Staerk J, Delhommeau F, Lacout C, Garçon L, Raslova H, Berger R, Bennaceur-Griscelli A, Villeval JL, Constantinescu SN, Casadevall N, Vainchenker W. A unique clonal JAK2 mutation leading to constitutive signalling causes polycythaemia vera. Nature 2005;434:1144-1148.

14. Baxter EJ, Scott LM, Campbell PJ, East C, Fourouclas N, Swanton S, Vassiliou GS, Bench AJ, Boyd EM, Curtin N, Scott MA, Erber WN, Green AR; Cancer Genome Project. Acquired mutation of the tyrosine kinase JAK2 in human myeloproliferative disorders. Lancet 2005;365:1054-1061.

15. Kralovics R, Passamonti F, Buser AS, Teo SS, Tiedt R, Passweg JR, Tichelli A, Cazzola M, Skoda RC. A gain-of-function mutation of JAK2 in myeloproliferative disorders. N Engl J Med 2005;352:1779-1790.

16. Ugo U, Marzac C, Teyssandier I, Larbret F, Lécluse Y, Debili N, Vainchenker W, Casadevall N. Multiple signaling pathways are involved in erythropoietin-independent differentiation of erythroid progenitors in polycythemia vera. Exp Hematol 2004;32:179-187. 
17. Jones AV, Kreil S, Zoi K, Waghorn K, Curtis C, Zhang L, Score J, Seear R, Chase AJ, Grand FH, White H, Zoi C, Loukopoulos D, Terpos E, Vervessou EC, Schultheis B, Emig M, Ernst T, Lengfelder E, Hehlmann R, Hochhaus A, Oscier D, Silver RT, Reiter A, Cross NC. Widespread occurrence of the JAK2 V617F mutation in chronic myeloproliferative disorders. Blood 2005;106:2162-2168.
18. Oh ST, Gotlib J. JAK2 V617F and beyond: role of genetics and aberrant signaling in the pathogenesis of myeloproliferative neoplasms. Expert Rev Hematol 2010;3:323-337.

19. Thiele J. Philadelphia chromosome-negative chronic myeloproliferative disease. Am J Clin Pathol 2009;132:261-280.

20. Choo KB. Epigenetics in disease and cancer. Malays J Pathol 2011;33:61-70. 